\title{
The Effect of Process Oriented Writing Activities on the Achievement and Attitude of the Preservice Primary School Teachers: An Example of Mixed Method Study
}

\author{
Emine Gül Özenç ${ }^{1}$ \\ ${ }^{1}$ Department of Primary Teaching, Faculty of Education, Niğde University, Turkey \\ Correspondence: Emine Gül Özenç, Assit. Prof. Dr., Department of Primary Teaching, Faculty of Education, Niğde \\ University, Turkey.
}

Received: July 14, 2016

Accepted: August 3, 2016

Online Published: October 29, 2016

doi:10.11114/jets.v4i11.1736

URL: http://dx.doi.org/10.11114/jets.v4i11.1736

\begin{abstract}
The purpose of this study is to find out whether process oriented writing exercises/activities have any effect on the achievement and attitude of preservice teachers as well as to set forth the opinions of primary preservice teachers on process oriented writing approach. In the research one classroom was designated as experimental group $(\mathrm{N}=35)$ while another was determined as control group $(\mathrm{N}=35)$ for the study which took 11 weeks to conclude. The results show that process oriented writing exercises were highly influential in terms of improving achievement and attitude of preservice primary school teachers. Besides, preservice teachers told important opinions about these activities.
\end{abstract}

Keywords: pre-service primary school teachers, process oriented writing activities, achievement, attitude, mixed method

\section{Introduction}

Today there are myriad ways of communication. Especially after the introduction of the internet and the smart phones to everyday life in the recent past, older communication methods have now begun to be forgotten. However, no matter how many communication methods exist, there is always a need for written communication. A good level "Writing comprises a set of skills which display students' capacity of observation, imagination, logical thinking, and ability to consider and arrange thoughts, transfer information and use mother tongue (Belet, 2008; Akyol, 2000). Writing is expressing what is said orally in certain symbols and it is one of the natural and expressive human behaviors (Özbay, 2009). According to Güneş (Güneş, 2007), writing is transferring information structured in the brain into the writing.

Improvement of writing skills may vary depending on the frequency and regularity of practice. In this study, process oriented writing approach was adopted and relevant activities were carried out.

Written communications have become an important issue for business organizations (Amiri Aghdaie et al., 2012; Raisi, 2015; Raisi and Pourmiri, 2015), educational organizations (Raisi and Asadzadeh, 2015, 2016), non-profit organizations, and indivuduals (Raisi and Pourmiri, 2016) in recent years and its necessary to study this important topic in order to better understand the power of written communications.

\subsection{Process Oriented Writing Approach}

First research into teaching of writing dates back to 1070's and Emig (1071), Perl (1979), Flower \& Hayes (1981) are considered leading researchers in process oriented writing (Cited in Dahaj, 2012). Process oriented approach in writing was developed in line with the structuralist approach which was put in general use in education. In process oriented approach, it is important after which stages of the process of writing the students produced the written text (Temizkan, Yalçınkaya, 2013). Researchers look into process oriented writing through different but complementary points of view. For example, James Mc Crimmon (1994; Cited in Sun, Feng, 2009) consider process oriented approach as differences in writing as an indicator of knowing (process).

According to Oral (2012), writing is a process studied with two main approaches. First approach is based on the product while the other is based on the process. The philosophy behind the process approach is different. Here, writing is regarded as the discovery, renewal and transformation of the thoughts and the language, through this approach, different processes and sub-skills arising before and during writing are studied and strategies are developed accordingly (Oral, 2012). In other 
words, this novel approach highlights the necessity to dwell on the process which is the answer to the question of "how" the text was written instead of the product, answer of "what" was written (Ülper, 2008). Similarly, Leki (1991) states that process approach emphasizes stages of the process of writing rather than the end product. Zamel (1983) considers writing as an exploration and discovery process carried out by the students simultaneously with evaluating and making sense of their thoughts. At every stage of this process, students also learn drafting, revising, arranging and publishing strategies which contribute to writing freely and achieving a quality product (Raimes 1983, Stewart and Cheung 1989, White and Arndt 1991, Cited in Ho, 2006). Different writing and assessment stages suggested by the researches exist in the writing model which was developed based on process based learning approach. Accordingly, writing process based on Planned Writing and Assessment consists of the preparation, drafting a text, revising draft, editing the text and presenting-publishing the text stages (Karatay, 2011).

\subsection{Problem}

The problem in this study is to test the impact of the conventional teaching method and process oriented writing approach taught as parts of "Turkish I: Written Expression" class on success and attitude of pre-service primary school teachers and study preservice teachers' opinions on related activities. In this parallel, answers for following questions were sought for:

1. Is there any meaningful difference between the pre and post-test marks of experimental and control groups in terms of achievement?

2. Is there any meaningful difference between the attitude points achieved by experimental and control groups at pre and post-tests?

3. Is there any meaningful difference between the pre and post-test achievement marks of experimental group?

4. Is there any meaningful difference between the pre and post-test attitude marks of experimental group in terms of achievement?

5. Is there any meaningful difference between the pre and post-test achievement marks of control group?

6. Is there any meaningful difference between the pre and post- test attitude marks of control group?

7. What are the opinions of pre-service primary school teachers regarding Turkish I: Written Expression Class carried out in accordance with process oriented writing approach?

\section{Method}

This study incorporates different points of view by combining qualitative and quantitative research, thus it was designed with mixed research method which is referred as "more than one way of seeing" and which brings about a broad field of application (Dede \& Demir, 2014).

The first and experimental part of the study was designed in accordance with quantitative method, which uses pre and post-test model with control group and was carried out experimentally. Pre and post-test model with control group consists of two groups which were determined by unbiased appointment. With both groups measurements are made before and after experiment. Presence of pre- tests in the model helps know the level of similarity between the groups prior to the experiment and correct post test results accordingly. In this model, to find out how efficient " $\mathrm{x}$ " is, pre and post-test scores used together (Karasar, 2005).

In the second part of the study, qualitative research method was used. Accordingly, the researcher distributed to the students five structured interview forms consisting of five questions related to "Turkish I: Written Expression" class carried out in accordance with process oriented writing approach and asked the students answer all the questions within 60 minutes. At the end of the class, the answers of the students were collected by the instructors. The questions in the interview were studied by 5 experts and finalized by the researcher.

\subsection{Working Group}

Experimental working group of the study consists of 70 first year students at Niğde University, Faculty of Education, Primary Teaching in 2013-2014 academic year. Control group consists of 35 students of primary teaching studying at classroom 1B while experimental group consists of equal number of students studying at classroom 1A. The groups were determined using unbiased appointment method. 37 teachers participated in the qualitative part of the study. Accordingly, interview forms structured by the researcher were filled out by the pre-service teachers at the end of the study and the researcher analyzed these forms in accordance with qualitative research techniques by dividing them into codes, categories and themes.

\subsection{Implementation Process}

Implementation process for experimental and control groups was started in the first semester of 2013-2014 academic year, in October 2013 and ended in January 2014, taking 11 weeks in total. With the experimental group, teacher candidates 
were briefed about "Turkish I: Written Expression" class in the first hour of lesson and relevant details about the process were given. Accordingly, Turkish I: Written Expression course content was prepared in accordance with process oriented approach and a calendar of weekly activities was set. In accordance with this calendar, each week one hour of theory teaching and practice classes every other week was carried out. Essays written by the students as a part of the activities were assessed by the instructor and both written and oral feedbacks were given about them. Each week instructors assessed the essays on specific topics written by the students using "Writing Skills Assessment Scale" (Göçer, 2005, Göçer, 2011). Writing activities carried out as parts of "Turkish I: Writing Expression" prepared in accordance with process oriented writing approach were in parallel with the subjects of theory classes. The students occasionally wrote on the set subjects with music or pictures in the background. In the classes sample essays were read aloud and deficiencies of the students were discussed. At the end of the term, a classroom magazine consisting of best samples of texts written by the students was prepared. Throughout the process, the instructor was constantly in touch with the students, to prepare the magazine extra meetings were organized. Apart from these, at the first and last course hours of the implementation, "Written Expression Attitude Scale" developed by Bağc1 (2007) was applied, following the activities the students were distributed structured interview forms and their opinions regarding the process were taken.

With the control group, the class was carried out with conventional teaching method and process oriented approach was not in use. Same measurement tools were also used for that group and "Written Expression Attitude Scale" and "Writing Skill Assessment Scale" were applied at the beginning and end of the academic year.

\subsection{Data Collection Tools}

The data used in the study were obtained through sample texts written by the students, Written Expression Attitude Scale, Writing Skill Assessment Scale and Structured Interview Form. Necessary procedure for the credibility of the Writing Skill Assessment Form was also undertaken. Accordingly, compositions written by the control group students (n: 35 ) were assessed two times at irregular intervals and based on the relation between the two, person correlation coefficient was calculated. According to Büyüköztürk (2006:32), coefficient falling between 0.70-1.00 is defined as a high correlation while the range between $0.70-0.30$ is average and $0.30-0.00$ is low correlation. At this study, this value was found as .781 (high). Pre- test compositions of the control group students were also assessed two times at different intervals and person correlation coefficient value for this group was found also high .834. Both values are substantially high in terms of credibility coefficient. Cronbach alpha coefficient of the "Written expression attitude scale" used in the study was found as .812 (high).

\subsection{Analysis of Data}

Quantitative part of the study data was analyzed using SPSS 21 programme pack and person correlation coefficient, independent groups $\mathrm{t}$ test, dependent groups t test and frequency were calculated. Qualitative part of the study was analyzed using content analysis and data obtained from structured interview forms were defined under various categories, themes and codes. Students responses in structured interview forms are numbered between S1-S21.

\section{Findings}

In this section data are evaluated with quantitative and qualitative techniques:

Table 1. Calculation of Pearson Correlation Coefficient of Experimental Group Achievement Test

\begin{tabular}{llll}
\hline & & $\begin{array}{l}\text { Achievement } \\
\text { pre-test1 }\end{array}$ & $\begin{array}{l}\text { Achievement } \\
\text { pre-test2 }\end{array}$ \\
\hline Achievement pre-test1 & Pearson & 1 &, $781^{* * *}$ \\
& Correlation & & 0 \\
& $\mathrm{p}$ & 35 & 35 \\
Achievement pre-test2 2 & Pearson &, $781^{* *}$ & 1 \\
& Correlation & & \\
& $\mathrm{p}$ & 0 & 35 \\
\hline
\end{tabular}

Table 1 shows Pearson correlation coefficient of the experimental group which is .781. This is considered as quite a high value (Büyüköztürk, 2006).

Table 2 shows Pearson correlation coefficient of the experimental group which is .834 . This is considered as quite a high value (Büyüköztürk, 2006). 
Table 2. Calculation of Pearson Correlation Coefficient of Control Group Achievement Test

\begin{tabular}{llll}
\hline & & Control 2 pre-test & Control \\
\hline Control 2 pre-test & Pearson & 1 &, $834^{* * *}$ \\
& Correlation & & \\
& $\mathrm{p}$ & & 0 \\
Control & $\mathrm{N}$ & 35 & 35 \\
& Pearson &, $834^{* *}$ & 1 \\
& Correlation & & \\
& $\mathrm{p}$ & 0 & 35 \\
\hline
\end{tabular}

Table 3. Comparing Pre- Test Results of Experimental and Control Groups with Independent Groups T-Test

\begin{tabular}{llllllll}
\hline & Group & $\mathrm{N}$ & $\mathrm{X}$ & $\mathrm{S}$ & $\mathrm{Sd}$ & $\mathrm{t}$ & $\mathrm{p}$ \\
\hline Achievement & Exp. & 35 & 62.17 & 4.637 & & & \\
pre-test & control & 35 & 62.20 & 4.303 & 68 & -.027 & .979 \\
\hline
\end{tabular}

According to Table 3 there is no meaningful difference between pre-test achievement marks of experimental and control groups before the implementation of process oriented writing approach ( $p>.05)$. This finding shows achievement marks of both groups are very close before the implementation.

Table 4. Comparing Post Test Marks of Experimental and Control Groups with Independent Groups T-Test

\begin{tabular}{llllllll}
\hline & Group & $\mathrm{N}$ & $\mathrm{X}$ & $\mathrm{S}$ & $\mathrm{df}$ & $\mathrm{t}$ & $\mathrm{p}$ \\
\hline Achievement & Experimental & 35 & 84.66 & 3.253 & & & \\
post test & Control & 35 & 61.40 & 4.972 & 68 & 23.157 & .000 \\
\hline
\end{tabular}

According to Table 4 there is a meaningful difference as much as .001 between post-test achievement marks of experimental and control groups $(\mathrm{p}<.001)$. This finding shows that experimental group which studied process oriented writing approach proved to be much more successful after the implementation.

Table 5. Comparing Pre-Test Attitude Marks of Experimental and Control Groups with Independent Groups T-Test

\begin{tabular}{llllllll}
\hline & Group & $\mathrm{N}$ & $\mathrm{X}$ & $\mathrm{S}$ & $\mathrm{df}$ & $\mathrm{t}$ & $\mathrm{p}$ \\
\hline Experimental & Experimental & 35 & 55.00 & 8.218 & 68 & & \\
pre- test & Control & 35 & 58.29 & 5.518 & 59.479 & -1.964 & .054 \\
\hline
\end{tabular}

According to Table 5 there is no meaningful difference between pre-test attitude marks of experimental and control groups $(\mathrm{p}>$.05). However, considering arithmetical mean $(\mathrm{X})$, attitude marks of the control group was more than the experimental group's (Experimental $\mathrm{X}=55$, Control $\mathrm{X}=58.29$ ).

Table 6. Comparing Post Test Attitude Marks of Experimental and Control Groups with Independent Groups T- Test

\begin{tabular}{llllllll}
\hline & Group & $\mathrm{N}$ & $\mathrm{X}$ & $\mathrm{S}$ & $\mathrm{df}$ & $\mathrm{t}$ & $\mathrm{p}$ \\
\hline Attitude post & Experimental & 35 & 58.51 & 6.900 & & & \\
& Control & 35 & 57.40 & 6.848 & 68 & .678 & .500 \\
\hline
\end{tabular}

According to Table 6 there is no meaningful difference between pre-test attitude marks of experimental and control groups ( $\mathrm{p}>.05)$. However this table also shows after the implementation of process oriented writing activities, the arithmetical mean of the experimental group visibly rose and exceeded the mean of the control group. (Exp. X=58.51, Control X=57.40). When Table 5 and Table 6 compared differences can be observed.

Table 7. Comparing Pre-Post Test Achievement Marks of the Experimental Group with the Dependent Groups T-Test

\begin{tabular}{lllllll}
\hline Experimental & $\mathrm{N}$ & $\mathrm{X}$ & $\mathrm{S}$ & $\mathrm{df}$ & $\mathrm{t}$ & $\mathrm{p}$ \\
\hline Achievement Pre-test & 35 & 62.17 & & & & \\
Achievement Post-test & 35 & 84.66 & 3.253 & 34 & -27.725 & .000
\end{tabular}

According to Table 7 , there is a meaningful difference of .001 between the achievement marks of pre-test and post-tests of the experimental group $(\mathrm{p}<.001)$. This finding shows process oriented writing activities are highly influential on the achievement of preservice teachers. Besides, arithmetical mean of the achievement results of pre-test and post-tests rise considerably. (Achievement pre- test $\mathrm{X}=62.17$, Achievement post-test $\mathrm{X}=84.66$ ).

Table 8. Comparing Pre-Post Test Attitude Marks of the Experimental Group with the Dependent Groups T-Test

\begin{tabular}{cllllll}
\hline Experimental & $\mathrm{N}$ & $\mathrm{X}$ & $\mathrm{S}$ & $\mathrm{df}$ & $\mathrm{t}$ & $\mathrm{p}$ \\
\hline $\begin{array}{l}\text { Attitude } \\
\text { pre-test }\end{array}$ & 35 & 55.00 & 8.218 & & & \\
$\begin{array}{c}\text { Attitude } \\
\text { post-test }\end{array}$ & 35 & 58.51 & 6.900 & 34 & -3.004 & .005 \\
\hline
\end{tabular}


Table 8 shows a meaningful difference of 0.1 between the pre and post-test of the experimental group ( $p<.01$ ). This finding shows process oriented writing activities are highly influential on the post-implementation attitudes of preservice teachers. Besides, arithmetical mean of the attitude results of pre-test and post-tests rise considerably. (Attitude test X=55, Attitude post-test $\mathrm{X}=58.51$ ).

Table 9. Comparing Pre-Post Test Achievement Marks of the Control Group with the Dependent Groups T-Test

\begin{tabular}{lllllll}
\hline Control & $\mathrm{N}$ & $\mathrm{X}$ & $\mathrm{S}$ & $\mathrm{df}$ & $\mathrm{t}$ & $\mathrm{p}$ \\
\hline \multicolumn{1}{|c}{ Achievement pre-test } & 35 & 62,2 & 4,303 & & & \\
Achievement post & 35 & 61,4 & 4,972 & 34 & 1.167 & .257 \\
test & & & & & & \\
\hline
\end{tabular}

According Table 9 there is no meaningful difference between the pre and post-test achievement marks of the control group ( $p>.05)$. This finding shows "Turkish I: Writing Expression" class carried out with the conventional teaching methods are not influential on the achievement of the control group students.

Table 10. Comparing Pre-Post Test Achievement Marks of the Control Group with the Dependent Groups T-Test

\begin{tabular}{cllllll}
\hline Control & $\mathrm{N}$ & $\mathrm{X}$ & $\mathrm{S}$ & $\mathrm{df}$ & $\mathrm{t}$ & $\mathrm{p}$ \\
\hline $\begin{array}{l}\text { Attitude } \\
\text { pre-test }\end{array}$ & 35 & 58,29 & 5,518 & & & \\
$\begin{array}{l}\text { Attitude } \\
\text { post-test }\end{array}$ & 35 & 57,4 & 6,848 & 34 & .974 & .337 \\
\hline
\end{tabular}

Table 10 shows no meaningful difference between the pre and post-test attitude marks of the control group ( $\mathrm{p}>.05$ ). This finding shows "Turkish I: Written Expression" class carried out with the conventional teaching methods are not influential on the attitude of the control group students.

Table 11. Themes, Categories and Codes related to the question "Please write your opinions on the writing activities you carried out."

\begin{tabular}{|c|c|c|c|c|c|c|c|}
\hline \multicolumn{4}{|c|}{ Positive Aspects } & \multicolumn{4}{|l|}{ Negative Aspects } \\
\hline $\begin{array}{l}\text { Emotional } \\
\text { Dimension }\end{array}$ & $\mathrm{F}$ & $\begin{array}{l}\text { Functional } \\
\text { Dimension }\end{array}$ & $\mathrm{F}$ & $\begin{array}{l}\text { Emotional } \\
\text { Dimension }\end{array}$ & $\mathrm{F}$ & $\begin{array}{l}\text { Functional } \\
\text { Dimension }\end{array}$ & $\mathrm{F}$ \\
\hline $\begin{array}{l}\text { They are } \\
\text { enjoyable and } \\
\text { fun to do }\end{array}$ & 15 & $\begin{array}{l}\text { They develop } \\
\text { writing and } \\
\text { expressing } \\
\text { skills }\end{array}$ & 18 & $\begin{array}{l}\text { Difficulty in } \\
\text { transferring the } \\
\text { tohoughts onto } \\
\text { the paper }\end{array}$ & 4 & $\begin{array}{l}\text { Difficulty in } \\
\text { hand writing }\end{array}$ & 4 \\
\hline $\begin{array}{l}\text { They } \\
\text { motivate to } \\
\text { take the class }\end{array}$ & 5 & $\begin{array}{l}\text { They provide } \\
\text { opportunity for } \\
\text { self-assessment }\end{array}$ & 2 & $\begin{array}{l}\text { Difficulty in } \\
\text { concentrating }\end{array}$ & 3 & $\begin{array}{l}\text { Not enough } \\
\text { time }\end{array}$ & 3 \\
\hline $\begin{array}{l}\text { They } \\
\text { motivate to } \\
\text { write }\end{array}$ & 3 & & & $\begin{array}{l}\text { Thoughts of } \\
\text { having no skill } \\
\text { for writing }\end{array}$ & 3 & $\begin{array}{l}\text { Inconvenient } \\
\text { classroom } \\
\text { environment }\end{array}$ & 2 \\
\hline $\begin{array}{l}\text { They provide } \\
\text { relaxation }\end{array}$ & 1 & & & $\begin{array}{l}\text { That they are } \\
\text { boring }\end{array}$ & 2 & & \\
\hline & & $\begin{array}{l}\text { They provide } \\
\text { activity (being } \\
\text { active) }\end{array}$ & 1 & Not liking them & 1 & & \\
\hline Total & 29 & & 21 & & 13 & & 9 \\
\hline
\end{tabular}

In accordance with the answers given to the question above, the most positive aspect in emotional dimension is that they develop writing and expression skills (f:18). According to the table, most of the opinions of the students regarding the process oriented writing activities are positive ( $f: 29, \mathrm{f}: 21)$. Some of the opinions of the students shown in the table are as follows: S1:

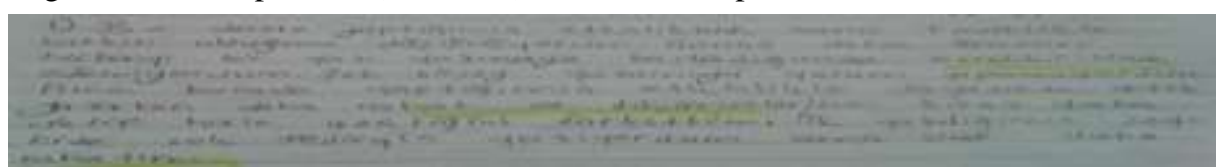

I believe the activities we carried out as part of this class definitely contributed to me as before these activities I was unable to express myself in writing. I could not write much and comment on things. Thanks to these activities now I am much more confident when writing and I realized my thoughts have become more active. I used to be more nervous when writing in the beginning but I am more relaxed now. S2:

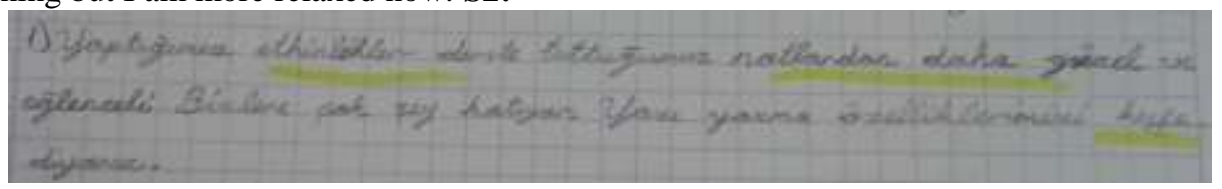


The activities we did were more beautiful and fun than keeping notes. They contribute to us a lot. We explore our writing abilities. S3:

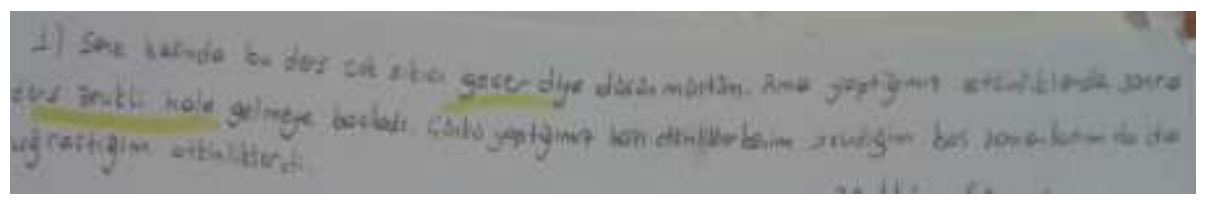

At the beginning of the academic year I thought to myself this class would be boring. But after the activities it became more and more enjoyable as I was also engaging with some of the activities at my leisure. S8:

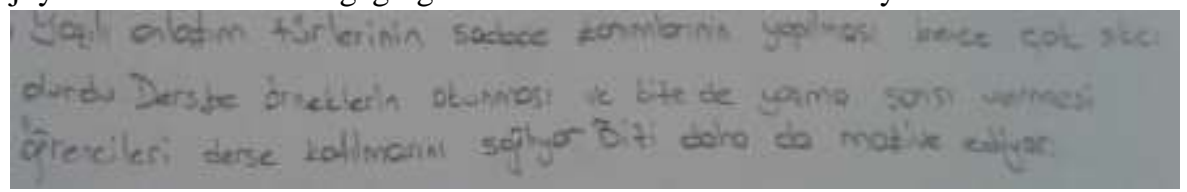

I think it would be boring if only the definitions of the written expression types were given. Reading sample texts aloud in the classroom and that the students are given the chance to write engages students in class. They further motivate us.

Table 12. Themes, Categories and Codes related to the question "What kind of contributions the writing activities have made to you? Please write your opinions."

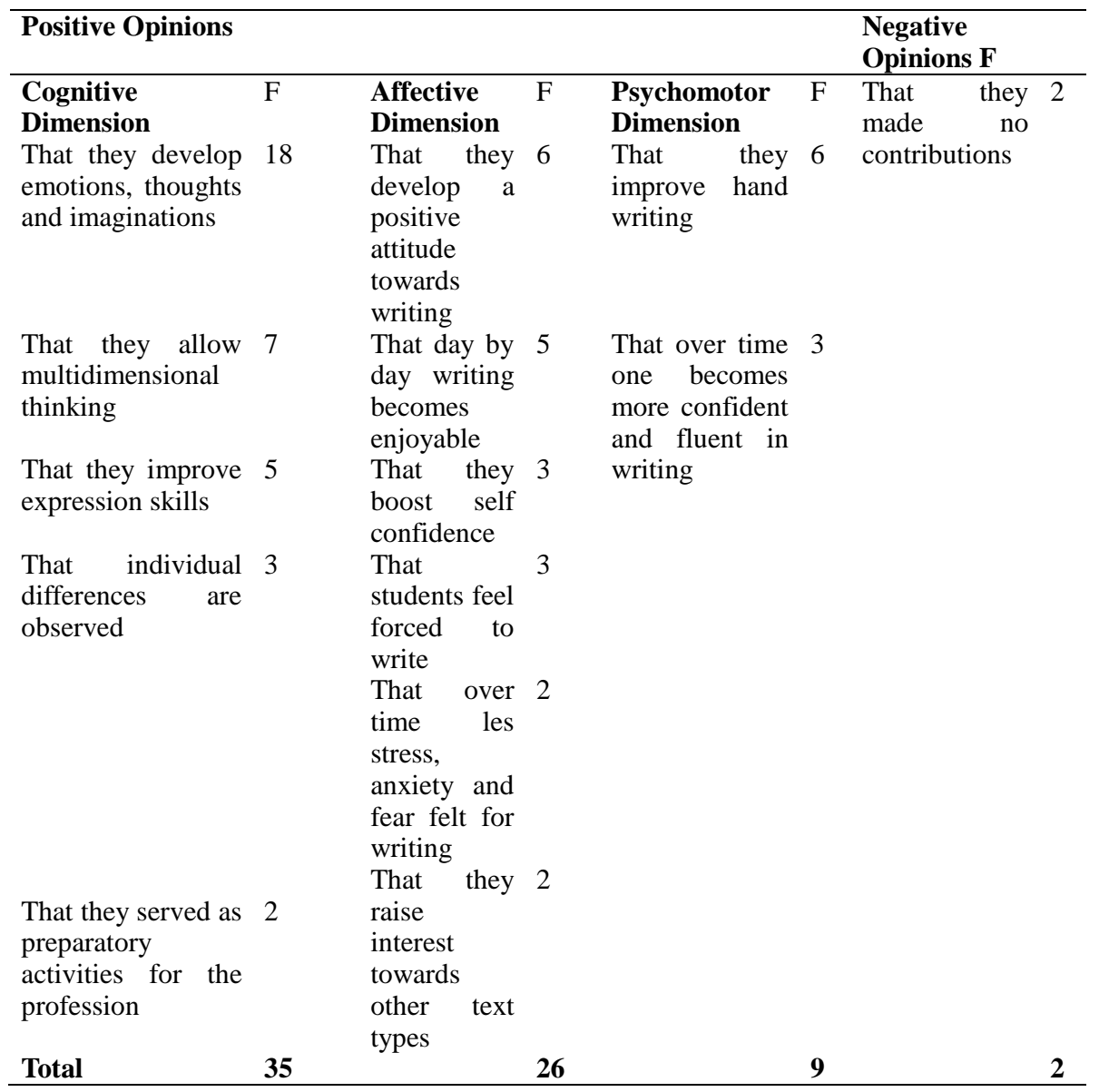

According to table 12, among the positive opinions about process oriented writing activities, under the cognitive category, that they develop students' emotions, thoughts and imagination comes first ( $f: 18$ ). Among the positive opinions, that they help developing positive attitude toward writing comes first (f:6). Under psychomotor category, the opinion that these activities develop students' hand writing comes first (f:6). Some opinions of students shown are as: S10:

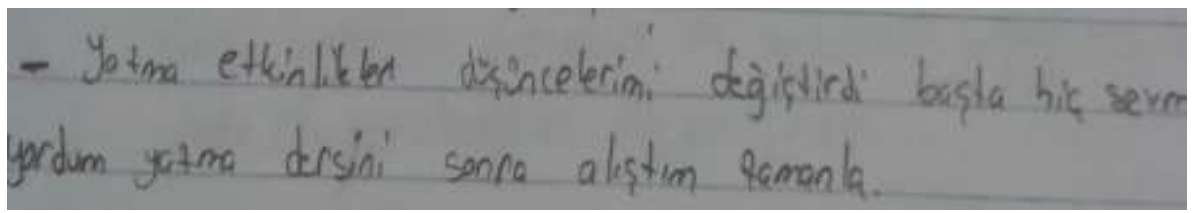


Writing activities changed my thoughts. In the beginning I didn't like writing classes at all but over I time I got used to it. S3:

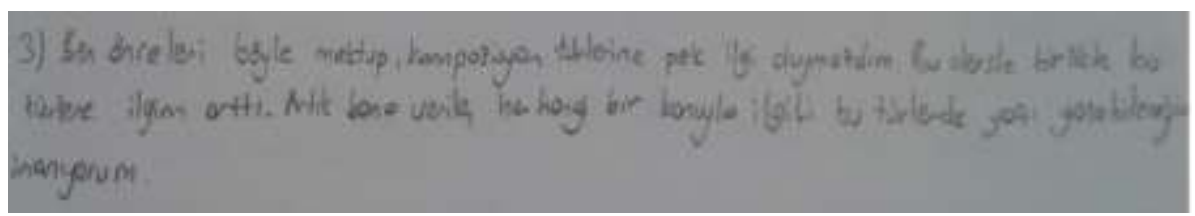

I used to be not much interested in this letter, composition types of writing. Thanks to these classes my interest towards these types has risen. Now I believe I can write on any given subject in these types. S11:

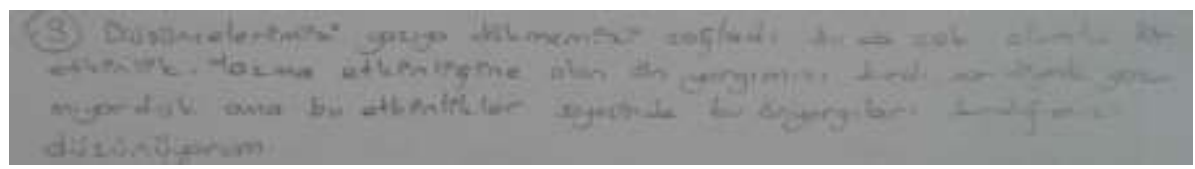

These activities allowed us put our thoughts into writing and this is quite positive. They helped us break our prejudices towards writing practices, we used to not write thinking it was a difficult thing to do but thanks to these exercises I believe we got over these prejudices. S12:

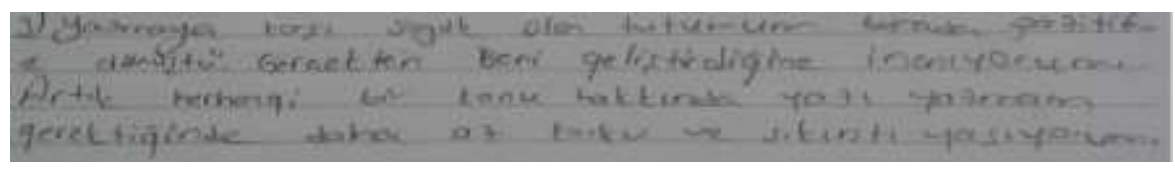

My attitude towards writing went from "cold" to positive. I really believe that these activities contributed to my development. Now I feel less afraid and nervous when I must write on any subject.

Table 13. Themes, Categories and Codes related to the question "Please write your opinions on whether writing activities had any effect on comprehension of the content of the class."

\begin{tabular}{|c|c|c|c|c|}
\hline \multicolumn{5}{|l|}{ Contributions } \\
\hline $\begin{array}{l}\text { Contributions to the lear } \\
\text { process }\end{array}$ & & $\mathrm{F}$ & $\begin{array}{l}\text { Contributions } \\
\text { individuality }\end{array}$ & $\mathrm{F}$ \\
\hline $\begin{array}{l}\text { Subjects became easier } \\
\text { comprehend. }\end{array}$ & to & 29 & They were very beneficial for us. & 6 \\
\hline Permanency established. & & 10 & $\begin{array}{l}\text { We were able to feel that this was } \\
\text { a written expression class. }\end{array}$ & 4 \\
\hline Subjects were reinforced. & & 8 & We learnt by writing and living. & 1 \\
\hline Theory put into practice. & & 4 & & \\
\hline More learning. & & 2 & & \\
\hline Faster learning. & & 2 & & \\
\hline Subjects concretized. & & 1 & & \\
\hline
\end{tabular}

According to Table 13, opinions of most of the students regarding the effect on writing activities on comprehension of the content of the course center on the code "subjects became easier to comprehend" under the category of contributions to the learning process (f:29). When contributions to the individuality theme is studied, "they were very beneficial for us" code is the first and that "We were able to feel that this was a written expression class" code comes as the second (f:6). Some of the student opinions are as follows: S14:

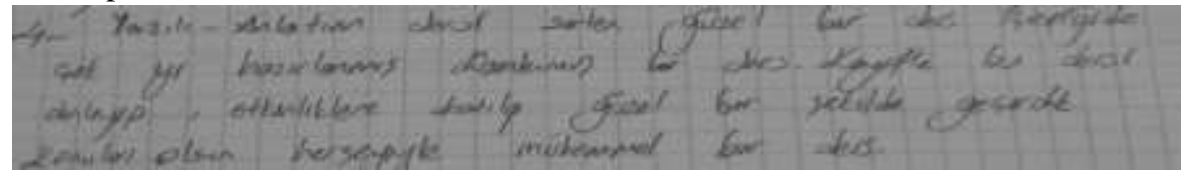

Written Expression is already a good class and content of it is well prepared and arranged. We listened to this class, took part in activities with pleasure. It is an excellent class both with the subjects it includes and everything. S4:

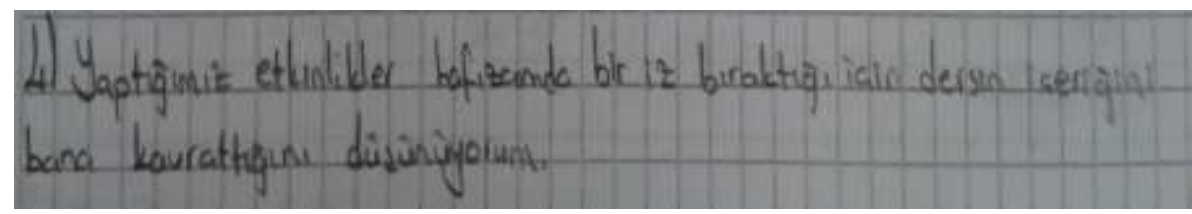

Since the activities we did left their marks in my memory I think they helped me comprehend the subject. S15:

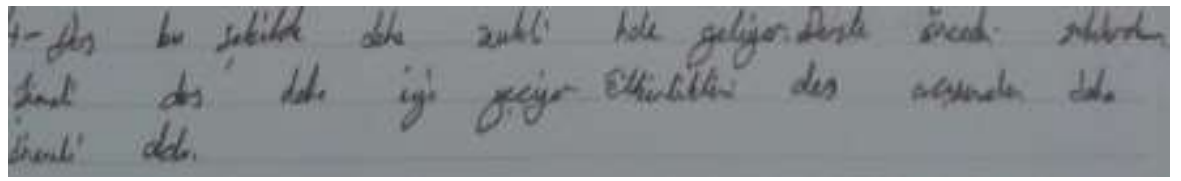


Class becomes more fun with these activities. I used to be get bored in the past now it got better. Activities became more important than the lesson. S19:

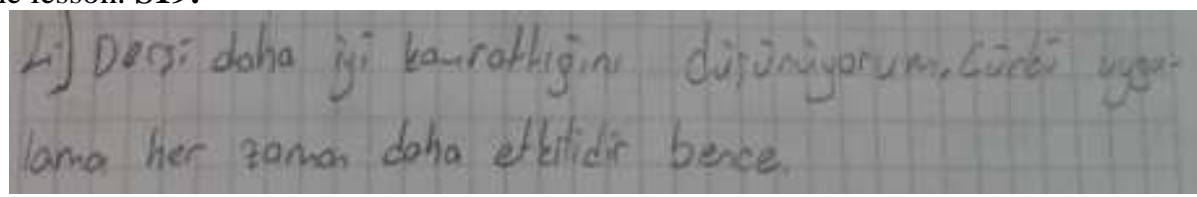

I think (activities) helped us better comprehend the class. Because I think practice is always more effective.

Table 14. Answers given to the question "Among the writing activities which one did you like most and which one did you find most difficult?"

\begin{tabular}{|c|c|c|c|c|c|c|c|}
\hline $\begin{array}{l}\text { Liked } \\
\end{array}$ & & & & Found difficul & & & \\
\hline Most liked & $\mathrm{F}$ & $\begin{array}{l}\text { I did not } \\
\text { like any of } \\
\text { them }\end{array}$ & $\bar{F}$ & $\begin{array}{l}\text { I did not } \\
\text { find any of } \\
\text { them } \\
\text { difficult }\end{array}$ & $\overline{\mathbf{F}}$ & $\begin{array}{ll}\text { The } & \text { most } \\
\text { difficult }\end{array}$ & $\mathrm{F}$ \\
\hline Letter & 14 & & 2 & & 1 & Poetry & 15 \\
\hline Memory & 9 & & & & & $\begin{array}{l}\text { Composition } \\
\text { with pictures }\end{array}$ & 10 \\
\hline Poetry & 7 & & & & & Story & 7 \\
\hline Story & 3 & & & & & Memory & 2 \\
\hline $\begin{array}{l}\text { Composition } \\
\text { with pictures }\end{array}$ & 3 & & & & & Letter & 1 \\
\hline Total & 36 & & 2 & & 1 & & 35 \\
\hline
\end{tabular}

According to the Table 14, the most liked written expression types are letter (f:14), memory (f:9), poetry (f:7) and story-composition with pictures (f:3) respectively. Two of the students did not like any of them. The types the students find most difficult are poetry (f:15), composition with pictures (f:10), story (f:7), memory (f:2) and letter (f:1) respectively. And one of the students told he/she found none of them difficult.

Table 15. Themes, Categories and Codes Related to the answers given to the question "Please explain your thoughts about the preparation of a magazine which consists of the products of the writing exercises"

\begin{tabular}{|c|c|c|c|c|c|}
\hline \multicolumn{6}{|c|}{ Impacts on Development } \\
\hline $\begin{array}{l}\text { Individual } \\
\text { Development }\end{array}$ & $\mathrm{F}$ & Social Development & $\mathrm{F}$ & $\begin{array}{l}\text { Individual and } \\
\text { Social Development }\end{array}$ & $\mathbf{F}$ \\
\hline $\begin{array}{l}\text { It encourages } \\
\text { writing }\end{array}$ & 7 & $\begin{array}{l}\text { It is important that } \\
\text { the writings are read } \\
\text { by others }\end{array}$ & 8 & $\begin{array}{l}\text { It is pleasant for } \\
\text { everyone }\end{array}$ & 14 \\
\hline $\begin{array}{l}\text { It leads to more } \\
\text { quality writings }\end{array}$ & 3 & $\begin{array}{l}\text { That it belongs } \\
\text { exclusively to the } \\
\text { classroom is good }\end{array}$ & 7 & $\begin{array}{l}\text { To see the reflection } \\
\text { of the efforts is good }\end{array}$ & 5 \\
\hline $\begin{array}{l}\text { It boosts } \\
\text { self-confidence }\end{array}$ & 2 & $\begin{array}{l}\text { It promotes sharing } \\
\text { with others }\end{array}$ & 5 & It is exciting & 4 \\
\hline $\begin{array}{l}\text { To see my name as } \\
\text { the author of a } \\
\text { writing makes me } \\
\text { happy }\end{array}$ & 2 & & & $\begin{array}{l}\text { It makes people feel } \\
\text { worthy }\end{array}$ & 2 \\
\hline Total & 14 & & 20 & It is a good memory & $\begin{array}{l}1 \\
26\end{array}$ \\
\hline
\end{tabular}

According to Table 15,the most opinions of the students regarding the prepation of a magazine which consists of the products of the writing activities are in: "It is pleasant for everyone (f:14)" code. Ö8:

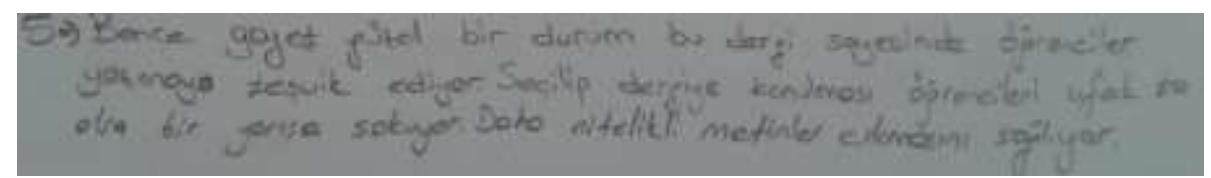

I think it is very good. By means of this magazine, the students are encouraged to write. They think that they are in a competition because the magazine chooses their works. It encourages students to write better. Ö9:

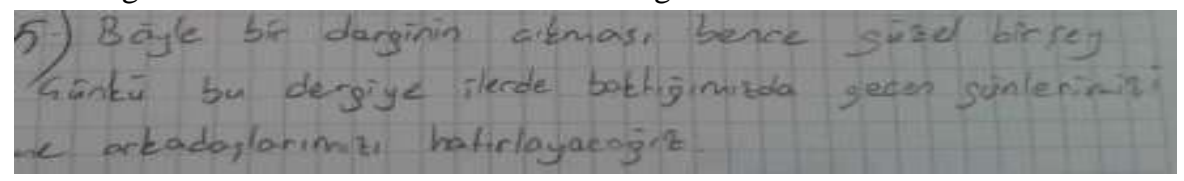


I think publishing such a magazine is very useful. Because when we look at this magazine in the future, we will remember our friends. Ö21:

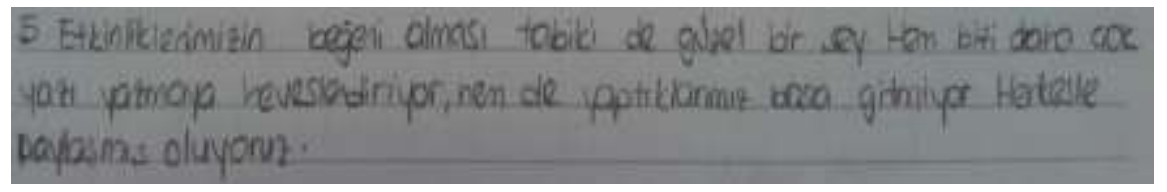

Of course, it is a good thing to be appreciated by others. It encourages us to write better. Our works are read and we share them with others. Ö17:

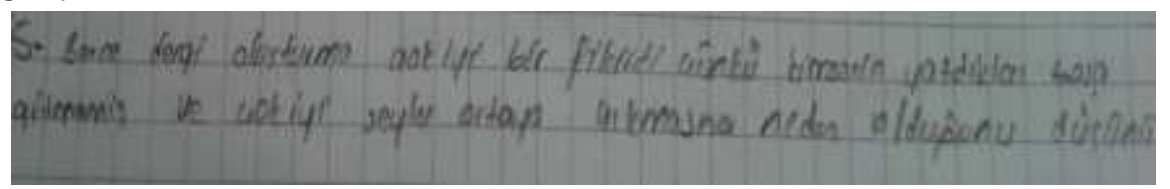

I think the idea of creating a magazine is a good one. The works do not go to waste and it helps us create better things.

\section{Result, Discussion and Recommendations}

This study explored the impact of process oriented writing exercises on achievement and attitude of the pre-service teachers and their opinions regarding this method. Accordingly, based on the study results, it is seen that the achievement scores of the experimental and control groups are very close before implementation of the study. Besides, that there is a significant difference between the post achievement scores of the both groups in favor of the experimental group shows us that using process oriented writing exercises in "Turkish I: Written Expression Class" has more positive impact on the achievement of the students.

Another result of the study shows that there is no meaningful difference between attitude scores of pre and post-tests of the experimental and control groups. This shows that although the groups were close to each other before the study and there is no meaningful difference following the study, if the arithmetical mean of the experimental group after the study has significantly risen, even exceed the arithmetical mean of the control group (Experimental X=58.51, Control X=57.40). Based on this, it may be said that although not visible, there is a difference in the attitude scores of the experimental group. Yet another result is that within the experimental group, there is a meaningful difference between the achievement and attitude scores of the pre and post-tests applied which leads us to say that process oriented writing activities have impact on the achievement and attitudes of the pre-service teachers. However, the same cannot be said for the pre and post test results of the control group. This shows that, "Turkish I: Written Expression" class carried out in accordance with the conventional methods do not have much influence on achievement and attitudes of the control group students.

Based on the analysis made using the qualitative methods and techniques, the first question of the structured interview distributed to the students was "Please write your opinions about the writing activities together with the reasons." Answer of most of the students was "it develops writing and expression skills" (f:18) and that "it is enjoyable and fun" (f:15). The second question of the qualitative study asked to the preservice primary teachers was "What kind of contributions do you think the writing exercises made to you?" The majority of the answers was "They developed emotions, thinking, imagination and mind" (f:18) The third question for the preservice primary teachers was "Please write your opinions regarding how the writing activities influenced comprehension of the content of the class by the students." Top answer was "The subjects were easily comprehended" followed by "Permanence was established. (f:10)"

The fourth question of the study was "Which one of the activities did you like most and which one did you find most difficult?" The students answers are as follows respectively: Letter (f:14), memory (f:9), poetry (f:7), story (f:3) and composition with pictures (f:3) While the genres which the students found most difficult are; poetry (f:15), composition with pictures (f:10), story (F:7), memory (f:2), letter (f:1). On the other hand, there are students which state they found none of the genres difficult (f:1) and they did not like any of the types (f:2). The fifth question "Please write your opinions on preparation of a magazine which consists of the products of the writing activities." was mostly answered as "It was pleasant for everybody (f:14)", followed by "It is important that the writings are read by others (f:8), "It encourages writing (f:7) and "That it belongs exclusively to the classroom is good (f:7)".

In their similar study, Pasand ve Haghi (2013) found process oriented approach has a positive effect on writing performance of the students as well as on punctuation, spelling, correct usage of capitals, tenses, subject-verb compliance, tenses, pronouns, possessive pronouns and conjunctions. Besides, the study of Dilidüzgün (2013) shows that process oriented writing activities make a meaningful difference in terms of the writing skill of the preservice primary teachers. Moreover, Tabak and Göçer's study (2013) states that, while the writing skill as stated in the program reflects the characteristics of the process oriented approach, however previous studies found that, in practice the classes are generally given in accordance with the product oriented writing approach and researchers think that this is the fundamental reason why the writing skill of the students are not at the desired level. Another study which confirms the findings of the current 
study was carried out by Hashemnezhad (2012) which assessed the writing skill of the Iranian students in terms of product, process and post-implementation period. Background of 60 students, between the ages 19-26 at Azat University were similar in terms of writing. Divided into 3 groups, 20 students each, carried out writing activities in accordance with these three approaches. Findings show post-implementation period has no advantage over the process oriented approach and both approaches were more effective on the students than the product oriented approach. A meta-analysis study carried out by Graham and Sandmel (2011) shows that process oriented writing approach created a statistically meaningful but comparatively less effect on the total writing quality of the students who study at common education class. Moreover, unlike other studies, this study states that process oriented approach does not increase the level of achievement of the students. In his study Göçer (2010) examined student compositions in terms of writing process components and textuality criteria and it is found that written expression works by the education faculty students were product oriented hence they partially meet textuality criteria. In addition to these studies, in their study named "Teaching Applied Writing Activities in different Teaching Models Using Process Oriented Writing Approach” Sun and Feng (2009) studied experimental and control groups in two different models. Accordingly, students of the experimental group on which process oriented writing approach was clearly applied, showed more progress than the control group students. Findings of Ülper and Uzun's study (2009) show that teaching programs prepared in accordance with process model enabled production of more quality texts by students. In his study, Ülper (2008) measured the impact of teaching program which uses process model on student achievement and found scores of the experimental group students were meaningfully higher than the scores of the control group students at each stage. Besides, post test results of the study showed that while experimental group made progress in terms of creating content, cohesiveness, corrects usage of words, building sentences, mechanical properties and total score while control groups made e meaningful progress in correct usage of words, building sentences and total core. Findings of the study show that teaching programs prepared in accordance with cognitive process approach leads to better texts written by students compared to the conventional programs. Lastly the study by Ho (2006) "Effects of process oriented writing approach on teaching of writing in six primary schools in Hong Kong" even though the results varied slightly across the classrooms, at top and bottom levels, process oriented approach was proved to be efficient for all the classrooms. In the study, process oriented approach was shown to be influential also in low-level classrooms and self-confidence of the students as well as their writing capabilities improved. It is seen that the results of the study are complementary to the other studies. This study shows that process oriented writing approach made significant contributions to improvement of the achievement, attitude, writing ability, skills and subskills of the students. In this parallel, following suggestions can be made:

- Primary school teachers, Turkish teachers and academics should be able to put process oriented process approach in practice when teaching.

-Workshops on process oriented writing activities for teachers can be organized by experts

-This study was carried out for 11 weeks however other longer time studies can be carried out as well.

\section{References}

Akyol, H. (2000). Teaching writing. Millî Ĕgitim Dergisi, 146, 37-48.

Aghdaie, S. F. A., Seidi, M., \& Riasi, A. (2012). Identifying the barriers to iran's saffron export by using porter's diamond model. International journal of marketing studies, 4(5), 129. http://dx.doi.org/10.5539/ijms.v4n5p129

Bagci, H. (2007). An Evaluation of the Attitudes of the Candidates of Teacher of Turkish Towards Written Expression and the Courses of Written Expression. TÜBAR-XXI,Bahar. Retrived from http://dergipark.ulakbim.gov.tr/tubar/article/viewFile/5000072939/5000067163

Büyüköztürk, Ş. (2006). Data analysis for the social sciences. PegemA Publication, Ankara.

Dahaj, M. A. (2012). Analyzing learners' language awareness in written production: product-oriented vs. process-oriented approaches. Linköping University Department of Culture and Communication Language and Culture in Europe Program Master's thesis. Retrived from http://www.divaportal.se/smash/get/diva2:588338/FULLTEXT01.pdf

Dede, Y., \& Demir, S. B. (2014). Karma yöntem araştırmalarının doğası. (İn) Karma yöntem araştırmaları. Translation editors Dede,Y., Demir, S.B. (Translated from Creswell, J.W., Plano Clark, V.L.). Anı Publication, Ankara (pp. 1-22).

Dilidüzgün, Ş. (2013). The effect of process writing activities on the writing skills of prospective Turkish teachers. Egitim Arastirmalari-Eurasion Journal of Educational Research, 52, 189-210. Retrived from http://www.ejer.com.tr/0DOWNLOAD/pdfler/eng/dild\%C3\%BCzg\%C3\%BCneng52.pdf

Göçer, A. (2005). The evaluation and testing in the teaching of Turkish in the second gradeof primary education. Unpublished doctorial dissertation, Atatürk University İnstitue of Social Science. Department of Turkish Education, Erzurum. 
Göçer, A. (2010). The assessment with the component of the process approach to writing and the criterions relevant to text of written expression skills of the education faculty students (The Sample of Niğde University). Kastamonu Ĕgitim Dergisi, 18(1), (pp.271-290). Retrived from http://www.kefdergi.com/pdf/18_1/18_20.pdf

Göçer, A. (2011). On evaluation written expression study of students by the turkish teachers. Ondokuz Mayls Üniversitesi Eğitim Fakültesi Dergisi 2011, 30(2), 71-97. http://dx.doi.org/10.7822/egt34

Graham, S., \& Sandmel, K. (2011). The process writing approach:A meta-analysis. The Journal of Educational Research. 104, 396-407, http://dx.doi.org/10.1080/00220671.2010.488703

Güneş, F. (2007). Turkish education and mental configuration. Ankara: Nobel Publication.

Hashemnezhad, H., \& Hashemnezhad, N. (2012). A comparative study of product, process, and post-process approaches in Iranian efl students' writing skill. Journal of Language Teaching and Research, 3(4), 722-729, doi:10.4304/jltr

Ho, B. (2006). Effectiveness of using the process approach to teach writing in six Hong Kong primary classrooms Perspectives: Working Papers in English and Communication, 17(1), 1-52.

Karasar, N. (2005). Scientific research methods. Ankara: Nobel Publication.

Karatay, H. (2011). Process based writing models: Planned writing and evaluation. Özbay, M. (Edit.)İn Writing education (2.Press) (pp.21-40). Ankara: PegemA Publication.

Leki, I. (1991). Teaching second language writing: where we seem to be. English Teacher Forum, April, 8-11.

Maltepe, S. (2006). An alternatıve for the written expression actıvities in turkısh language teaching: creatıve writing approach, 132, pp. 56-66, Ankara, 2006. Retrived from http://dergiler.ankara.edu.tr/dergiler/27/757/9637.pdf

Oral, G. (2012), Again, we are writing. Ankara: PegemA Publication.

Özbay, M. (2009). Turkish special teaching methods I (3. press). Ankara: Öncü Book.

Pasand, P. G., \& Haghi, E. B. (2013). Process-product approach to writing: the effect of model essays on EFL learners' writing accuracy. International Journal of Applied Linguistics \& English Literature, 2(1), 76-79.

Riasi, A. (2015). Competitive advantages of shadow banking industry: An analysis using Porter diamond model. Business Management and Strategy, 6(2), 15-27. http://dx.doi.org/10.5296/bms.v6i2.8334

Riasi, A., \& Asadzadeh, N. (2015). The relationship between principals' reward power and their conflict management styles based on Thomas-Kilmann conflict mode instrument. Management Science Letters, 5(6), 611-618. http://dx.doi.org/10.5267/j.msl.2015.4.004

Riasi, A., \& Asadzadeh, N. (2016). How Coercive and Legitimate Power Relate to Different Conflict Management Styles: A Case Study of Birjand High Schools. Journal of Studies in Education, 6(1), 147-159. http://dx.doi.org/10.5296/jse.v6i1.8946

Riasi, A., \& Pourmiri, S. (2015). Effects of online marketing on Iranian ecotourism industry: Economic, sociological, and cultural aspects. Management Science Letters, 5(10), 915-926. http://dx.doi.org/10.5267/j.msl.2015.8.005

Riasi, A., \& Pourmiri, S. (2016). Examples of Unsustainable Tourism in Middle East. Environmental Management and Sustainable Development, 5(1), 69-85. http://dx.doi.org/10.5296/emsd.v5i1.8705

Tabak, G., Göçer, A. (2013). 6-8. Evaluating the writing skill of sixth and eighth grade turkish language teaching curriculum in terms of product and process approaches. Ahi Evran Üniversitesi Kırşehir Eğitim Fakültesi Dergisi (KEFAD), 14(2),147-169.

Temizkan, M., \& Yalçınkaya, M. (2013). The state of 6-7-8th grade elementary turkish-language teachers in applying creative writing activities. Dicle Üniversitesi Ziya Gökalp Ë̆itim Fakültesi Dergisi, 20,70-91.

Sun, C., \& Feng, G. (2009). Process approach to teaching writing aplied in different teaching models. English Language teaching, 2(1), 150-155.

Ülper, H. (2008). Bilişsel süreç modeline göre hazırlanan yazma öğretim programının öğrenci başarısına etkisi. Unpublished doctorial dissertation, Ankara Üniversitesi Sosyal Bilimler Enstitüsü.

Ülper, H., \& Uzun, L. (2009). The effect of the writing programmeprepared in accordance with cognitive process model on student success. Illköğretim Online, 8(3), 651-665.

Zamel, V. (1982). Writing: The process of discovering meaning, TESOL Quarterly 16, 195-209. http://dx.doi.org/10.2307/3586792

\section{$(\mathrm{cc}) \mathrm{BY}$}

This work is licensed under a Creative Commons Attribution 3.0 License. 